\title{
Multidrug treatment of leprosy-practical application in Nepal
}

\author{
N M SAMUEL, SUSIE SAMUEL, N NAKAMI, \\ \& R MURMU \\ Anandaban Leprosy Hospital, PO Box 151, Kathmandu, Nepal
}

Accepted for publication 11 January 1984

\begin{abstract}
Summary In June 1981, 25 years after its first involvement in the treatment and control of leprosy, the Anandaban Hospital in Nepal introduced multiple drug therapy. The main objectives were: 1 , to treat all newly diagnosed patients, both pauci- and multibacillary; 2, to give multiple drug therapy to all active multibacillary cases, irrespective of previous treatment; and 3, to document the regularity of attendance of patients, including those living at great distances from the hospital clinic. Preliminary results are reported in a group of 348 patients.
\end{abstract}

\section{Introduction}

Many people in third world countries are affected by leprosy and this may perhaps be due to marginal living conditions and ineffective health care systems. In countries like Nepal, where leprosy is a major problem, it is estimated that there are twice as many unreported cases suffering from leprosy. ${ }^{1}$ The achievement of control is far distant or unattainable by current DDS-based practices and methods used for the control of the disease. In 1976, ${ }^{2}$ a WHO expert committee on leprosy emphasized the need for preventing the development of dapsone resistance and in its report recommended that all active bacteriologically-positive multibacillary patients be treated with at least two anti-leprosy drugs. The increase in emergence of dapsone-resistant leprosy is well known. The rapidly increasing prevalence in Nepal of multibacillary patients with mouse footpad proven secondary and primary dapsone resistance has been reported..$^{3,4}$

The Anandaban Leprosy Hospital has been involved in treatment and control of leprosy for the past 25 years in Nepal. In June 1981, a clinical and bacteriological evaluation of patients (Tables 1 and 2 ) showed that $514(49 \%)$ of multibacillary patients were still clinically active and smear positive. This justified the immediate introduction of multidrug treatment at the Skin Clinic, Shantha Bhawan Hospital (10 km from Anandaban), with the following objectives: (1) To 
administer multidrug treatment regimens to all newly-diagnosed patients, both paucibacillary and multibacillary leprosy patients; (2) to administer multidrug treatment regimens to all active multibacillary patients irrespective of previous treatment; and (3) to document the regularity of patients when regular home follow up may not be feasible as patients attend the clinic from all over the country. Shantha Bhawan Hospital was the first unit in Nepal to introduce multidrug therapy.

\section{Patients and methods}

1 A large proportion of the patients who attend the Skin Clinic at Shantha Bhawan Hospital present voluntarily and a further significant number are 'referred' by patients under treatment.

2 A total of 348 patients have been entered in the study, of these $199(57 \%)$ were newly diagnosed and had no previous treatment. $149(43 \%)$ patients, irrespective of past treatment and who were clinically active and bacteriologically positive for AFB were initiated on combined chemotherapy.

3 Retraining of all medical staff. We were aware of the urgent need to retrain the paramedical workers, nurses and laboratory technicians before patients could be administered the combined drugs at the Skin Clinic in Shantha Bhawan Hospital.

4 Premultidrug therapy education of patients. Paramedical workers and other medical staff including nurses, attending the weekly clinic explained to and discussed with patients what combined treatment for leprosy meant, the importance of regular attendance at the clinic, and of notifying side-effects and reactions. If the medical staff were not satisfied that the patient was ready to be included in the study, then with the patient's consent they were admitted to Anandaban Leprosy Hospital for intensive health education and to impress upon them that a shorter course of treatment would be effective.

5 Medical records. Medical records were designed to facilitate the recording of: identification of the patient (including the name of parent or spouse, address, sex, age and black and white photograph); dates of initial diagnosis, start of treatment; smear record; body charts; dates of supervised treatment given; drug side-effects; and reactions and treatment.

6 After obtaining the patient's consent and necessary information the doctor and the senior paramedical worker performed the clinical examination for leprosy and recorded their findings on a body chart. The patients were given a Ridley-Jopling classification, the following investigations were undertaken: (a) skin smears from 4 sites bacteriological and morphological indices; (b) pretreatment skin biopsy; (c) liver function tests and serum proteins; (d) chest X-ray; (e) sputum for AFB; (f) ESR, WBC, Hb; (g) urine-sugar/albumin; and (h) Mitsuda lepromin; leprosin A and tuberculin skin tests. Skin smears were repeated every 3 
months. Skin biopsies and liver function tests were repeated during the treatment period and after withdrawal of the drugs.

7 Drug regimen.

(A) Multibacillary patients:

Dapsone $100 \mathrm{mg}$ od

Clofazimine $100 \mathrm{mg}$ od

Unsupervised.

Rifampicin $600 \mathrm{mg}$

Two doses in a month

Unsupervised.

One dose supervised at the clinic.

Second dose supervised by the patient.

Duration. Till skin smears for AFB become negative.

(B) Paucibacillary patients:

Dapsone $100 \mathrm{mg}$ od

Unsupervised.

Rifampicin $600 \mathrm{mg}$

One dose supervised at the clinic.

Two doses in a month

Second dose supervised by the patient.

Duration. Six months.

8 Monthly clinic visits. At monthly visits the patient was identified, and complaints and side-effects, if any, were recorded. During the monsoon season a significant number of patients were given treatment for more than a month, up to 3 months maximum. Rifampicin is not given by proxy.

9 Post-multidrug therapy follow up.

A (i) Paucibacillary patients (Patients whose initial smears were positive): when 3 consecutive smears for AFB are negative and no sign of activity remains, these patients are requested to come for a follow-up examination every 6 months. (ii) Paucibacillary patients (Patients whose initial smears were negative): after 6 months of multidrug treatment these patients are kept under surveillance and requested to come for a follow-up examination every 6 months.

B Multibacillary patients: when 3 consecutive smears for AFB are negative and no active sign remains, patients are kept under surveillance and asked to report for follow-up examination every 6 months.

\section{Results}

Table 1 shows that 1057 multibacillary patients were registered in previous years at the Skin Clinic. $543(51 \%)$ were inactive and $514(49 \%)$ were active and bacteriologically positive. Out of 514 active patients only $108(21 \%)$ were taken for immediate administration of combined chemotherapy due to financial 
Table 1. Showing the clinical and bacteriological status of multibacillary patients attending the clinic and the year of registration of active patients

\begin{tabular}{|c|c|c|c|c|}
\hline \multicolumn{2}{|c|}{$\begin{array}{c}\text { No. of multibacillary } \\
\text { patients attending } \\
\text { clinic }\end{array}$} & $\begin{array}{c}\text { No. } \\
\text { inactive }\end{array}$ & \multicolumn{2}{|c|}{$\begin{array}{l}\text { No. active and } \\
\text { bacteriologically } \\
\text { positive }\end{array}$} \\
\hline \multicolumn{2}{|c|}{1057} & $543(51 \%)$ & \multicolumn{2}{|c|}{$514(49 \%)$} \\
\hline \multicolumn{5}{|c|}{ Active multibacillary patients year of registration } \\
\hline $1950-60$ & $1961-70$ & $1971-80$ & 1981 & Total \\
\hline $19(4 \%)$ & $102(20 \%)$ & $192(37 \%)$ & $201(39 \%)$ & $514(100 \%$ \\
\hline
\end{tabular}

constraints and non-availability of drugs. 108 patients are among those who received dapsone monotherapy for varying periods (Table 4).

Table 2 shows that a total of 348 patients form the multidrug treatment study. Of this, $255(73 \%)$ are male and $93(27 \%)$ are female. 90 patients are in the age group, 31-40 years.

From Table 3, it is seen that 199 newly-diagnosed leprosy patients are entered in the study. Newly-diagnosed patients form $57 \%$ of the study subjects. $142(71 \%)$ are male and $57(29 \%)$ are female. It is interesting to note that $77(39 \%)$ are BT and $12(6 \%)$ are TT type of patients.

Table 4 shows that 149 leprosy patients entered in the MDT study, received

Table 2. Shows 348 patients in the multidrug therapy study according to age and sex distribution

\begin{tabular}{lccc}
\hline Age group & Male & Female & Total \\
\hline $0-10$ & 5 & 4 & $9(25 \%)$ \\
$11-20$ & 21 & 18 & $39(11 \%)$ \\
$21-30$ & 54 & 24 & $78(22 \%)$ \\
$31-40$ & 70 & 20 & $90(26 \%)$ \\
$41-50$ & 55 & 14 & $69(20 \%)$ \\
$51-60$ & 33 & 11 & $44(13 \%)$ \\
$60>$ & 17 & 2 & $19(5 \%)$ \\
\hline Total & $255(73 \%)$ & $93(27 \%)$ & $348(100 \%)$ \\
\hline
\end{tabular}

Ratio of 2.7 male: 1.0 female. 
Table 3. Showing the number of newly diagnosed leprosy patients in the multidrug therapy study according to sex and type of leprosy

\begin{tabular}{lcccccccc}
\hline & TT & BT & BB & BL & LL & PN & IND & Total \\
\hline Male & 5 & 57 & 2 & 38 & 35 & 3 & 2 & 142 \\
Female & 7 & 20 & 1 & 13 & 15 & 1 & 0 & 57 \\
\hline Total & $12(6 \%)$ & $77(39 \%)$ & $3(2 \%)$ & $51(26 \%)$ & $50(25 \%)$ & $4(2 \%)$ & $2(1 \%)$ & $199(100 \%)$ \\
\hline
\end{tabular}

Table 4. Distribution of leprosy patients entered in the multidrug therapy study irrespective of the previous treatment

\begin{tabular}{lcccc}
\hline & BT & BL & LL & Total \\
\hline Male & 28 & 28 & 58 & 114 \\
Female & 13 & 4 & 18 & 35 \\
\hline Total & $41(28 \%)$ & $32(21 \%)$ & $76(51 \%)$ & $149(100 \%)$ \\
\hline
\end{tabular}

dapsone monotherapy for varying periods and are still active and bacteriologically positive. $43 \%$ of the study subjects are those who had previously received dapsone. 108 patients were from the old registered patients (Table 1) and 41 patients were referred from other clinics for management.

Figure 1 shows the distribution of 348 leprosy patients in Nepal receiving multidrug treatment at the Shantha Bhawan Hospital.

In Table 5 the results of post-MDT (6 months) follow up of borderline tuberculoid patients is shown. Of 77 newly-diagnosed BT patients (Table 3) 56 $(73 \%)$ patients have completed 6 months of combined treatment. The post-MDT follow up period varied from 3 to 16 months.

The observations of post-MDT follow up of 56 newly-diagnosed borderline tuberculoid patients are:

1 Initial lesions: that the lesions were unchanged up to 3 months on follow up. By 6 months we could observe the positive change in sensation. By 12 months onwards the original lesions were becoming vague and wrinkled in appearance. 2 New lesions: in all 56 BT patients no new lesions appeared. 3 Nerve damage: 2 patients developed ulnar neuritis at 10 months post-MDT follow up. One patient who on initial examination presented with type I reaction continued up to 12 months and was treated with cortico steroids. A total of $3(5 \%)$ BT patients suffered from neuritis during the follow up. 4 Smears for AFB: patients whose 


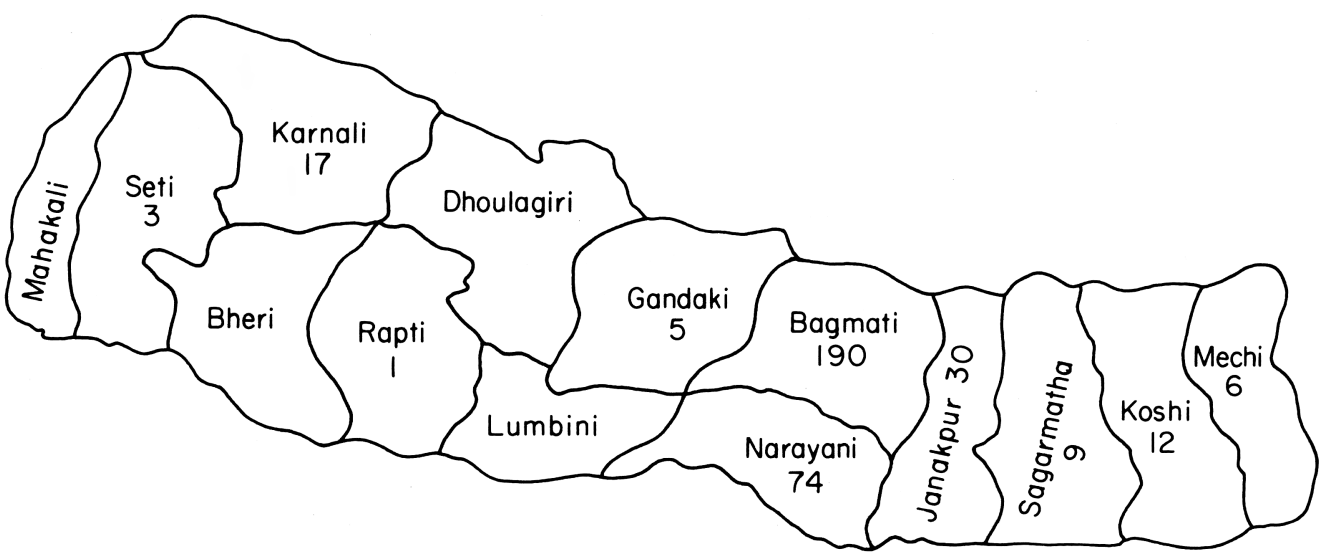

Figure 1. The distribution of 348 leprosy patients in Nepal receiving multidrug treatment at the Skin Clinic, Shanta Bhawan Hospital.

Table 5. Results of clinical observations on post MDT (6 months) follow up in 56 borderline tuberculoid patients

\begin{tabular}{|c|c|c|c|c|}
\hline $\begin{array}{l}\text { Duration of } \\
\text { follow up in } \\
\text { months after } \\
\text { completing } \\
6 \text { months of MDT }\end{array}$ & $\begin{array}{l}\text { No. of } \\
\text { patients }\end{array}$ & $\begin{array}{c}\text { New } \\
\text { lesions } \\
\text { observed }\end{array}$ & $\begin{array}{l}\text { Neuritis } \\
\text { detected }\end{array}$ & $\begin{array}{c}\text { Changes observed } \\
\text { in the initial } \\
\text { lesions }\end{array}$ \\
\hline $1-3$ & 8 & Nil & Nil & Lesion unchanged \\
\hline $4-6$ & 11 & Nil & Nil & $\begin{array}{l}\text { Lesion unchanged } \\
\text { sensation }+\end{array}$ \\
\hline $7-10$ & 11 & Nil & $\begin{array}{l}2 \text { patients } \\
\text { ulnar neuritis }\end{array}$ & $\begin{array}{l}\text { Lesion unchanged } \\
\text { sensation }+\end{array}$ \\
\hline $11-13$ & 13 & Nil & $\begin{array}{l}1 \text { patient } \\
\text { type I reaction }\end{array}$ & Lesions vague \\
\hline $14-16$ & 13 & Nil & Nil & $\begin{array}{l}\text { Lesions vague } \\
\text { wrinkling of } \\
\text { skin observed }\end{array}$ \\
\hline
\end{tabular}

smears were negative for AFB at cessation of treatment continued to be negative on follow up. 5 Histology of post-MDT follow up: this will be reported in another communication.

\section{Discussion}

Because of the disturbing, mouse foot pad proven primary and secondary dapsone-resistant leprosy in Nepal, the Leprosy Mission with the co-operation of 
His Majesty's Government of Nepal took the initiative to administer supervised multidrug treatment from a centralized clinic set up when 'defaulter retrieval' is impossible. As mentioned earlier, the patients come from very long 'walking distances' however, this has not deterred them from attending the clinic regularly. Of $348,13(4 \%)$ patients failed to visit the clinic regularly. In our experience the key to the successful implementation of multidrug therapy is the 'first contact' between the medical team and the patients and the enthusiasm of the multidrug therapy medical team.

A proportion of the multibacillary patients are receiving the 24th dose of intermittent therapy. Among 13 defaulters, $4(30 \%)$ are multibacillary patients (from Table 3). Efforts are being made to trace them with the co-operation of the local panchayat leaders. The bacterial clearance of BL/LL patients may take more than 24 months as the immune mechanisms in these patients are inadequate to eliminate the dead Mycobacterium leprae. Therefore, studies are in progress in active multibacillary patients to administer in addition to effective chemotherapy, a mixture of $\mathrm{BCG} / M$. leprae in multiple doses. ${ }^{5}$

It is reported that in administering rifampicin to $\mathrm{BT}$ patients there is a potential danger of nerve damage. ${ }^{6}$ With the exception of 3 BT patients on follow up, no further damage was observed in others.

Due to limited resources, priorities have to be drawn up for administration of combined chemotherapy for leprosy patients in a control programme. As shown in this study, our opinion is that multibacillary relapsing patients should have priority over paucibacillary patients. From an administrative and managerial point of view the latter group is important. ${ }^{7}$ The WHO study group recommendations are practical and can be applied in the field for control of leprosy. ${ }^{8}$ In our experience, it improves patients' compliance and permits frequent interaction between patient and multidrug therapy medical team.

\section{Acknowledgments}

We are most grateful to all the staff and patients and in particular to $\mathrm{Mr} \mathrm{P} \mathrm{K}$ Failbus, Business Manager, Messers B Shrestha, N Miyazaki, Mrs N Nakami and Monica Murmu.

We thank Chief, Leprosy Services Development Board, HMG/Nepal. We are grateful to The Leprosy Mission International for financial support and to $\mathrm{Mr} \mathrm{M}$ O Jacob for typing the manuscript.

\section{References}

1 Sansarricq H. Leprosy in the world today. Lepr Rev, 1981; 52 (Suppl): 15-31.

2 WHO Expert committee on leprosy. Fifth report. Technical report series No. 607, 1976. 
$272 \quad N$ M Samuel et al.

${ }^{3}$ Samuel N M, Samuel S, Loudon J, Neupani K, Adiga RB. Prevalence of secondary dapsone resistance in Nepal. (Accepted for publication in Lepr India.)

${ }^{4}$ Samuel NM, Samuel S, Loudon J. Primary dapsone resistant leprosy in Nepal. (Accepted for publication in Lepr India.)

${ }^{5}$ Convit J, Aranzazu N, Zuniga M, Ulrich Marian, Pinardi Maria, Castellazzi Z, Alvarado J. Immunotherapy and immunoprophylaxis of leprosy. Lepr Rev, 1983; Special issue; 475-605.

${ }^{6}$ Steenbergen GJ, Pfaltzgraff RE. Treatment of neuritis in borderline leprosy with rifampicin and corticosteroids-A pilot trial. Lepr Rev, 1975; 46: 115-18.

7 Askew AD. Report of a meeting on Action plans for leprosy control, New Delhi, 23-25 August 1982 (WHO/LEP/83).

8 WHO study group. Chemotherapy of leprosy for control programmes. Technical report series No. 675, 1982. 